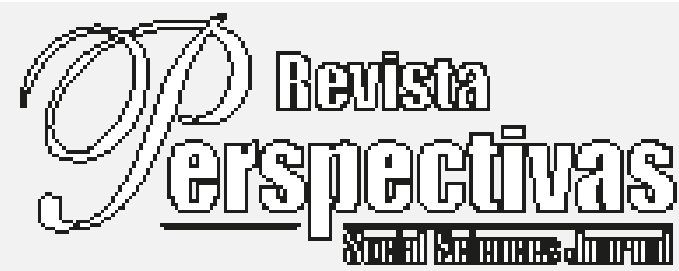

Artículo Original

https://doi.org/10.22463/25909215.2644

\title{
Affective domain and mathematical processes in teaching practice. a review from mathematical education
}

\author{
Dominio afectivo y procesos matemáticos en la práctica docente. Una revisión desde la Educación Matemática \\ Karen Natalia Patiño-Contreras ${ }^{1}$; Dayana Paola Gómez-Barbosa ${ }^{2}$; Yuretsy Alexandra Reyes-Cáceres ${ }^{3}$ \\ ${ }^{1}$ karennataliapc@ufps.edu.co,ORCID: 0000-0002-5669-9688,Universidad Francisco de Paula Santander,Cúcuta, Colombia \\ 2 barbosadayanapaolag@ufps.edu.co,ORCID: 0000-0002-4166-1142, Universidad Francisco de Paula Santander,Cúcuta, Colombia \\ 3yuretsyalexandrarc@ufps.edu.co,ORCID: 0000-0001-6862-8417, Universidad Francisco de Paula Santander,Cúcuta, Colombia
}

Cómo citar: K.N Patiño-Contreras, D.P Gómez-Barbosa, Y.A Reyes-Cáceres, “Affective domain and mathematical processes in teaching practice. a review from mathematical education”. Perspectivas, vol. 5, no. 1, pp. 57-67, 2020.

Recibido: September 05, 2019; Aprobado: November 10, 2019.

\begin{tabular}{|c|c|}
\hline & ABSTRACT \\
\hline $\begin{array}{l}\text { Key words: } \\
\text { teaching practice, } \\
\text { affective domain, } \\
\text { mathematical processes, } \\
\text { teacher training, } \\
\text { mathematics, } \\
\text { attitudes, } \\
\text { beliefs. }\end{array}$ & $\begin{array}{l}\text { This article is part of a macro research project entitled Influence of the affective domain, the mathematical } \\
\text { processes and the pedagogical practice of the teacher of Basic Education in the academic performance of } \\
\text { the student. This is a qualitative type of work with a descriptive and documentary approach, prepared by } \\
\text { students belonging to the SIEM nursery, with the purpose of making a bibliographic review of the different } \\
\text { investigations and theoretical contributions that have been made around this topic, obtaining a clear overview } \\
\text { and broad on the object of study. Taking as a starting point the bibliographic review of } 32 \text { research articles } \\
\text { that have been published in the last three decades, among which are books, articles from indexed journals, as } \\
\text { well as undergraduate, master's and doctoral studies. For the bibliographic review, several stages were taken } \\
\text { into account: search of antecedents for each construct, compilation of antecedents, selection of representative } \\
\text { information, categorization of each of the constructs and systematization. The results obtained allowed to } \\
\text { support the theoretical and epistemological foundations of each of the constructs that will later become part of } \\
\text { the theoretical framework of the advanced research. }\end{array}$ \\
\hline & RESUMEN \\
\hline $\begin{array}{l}\text { Palabras clave: } \\
\text { práctica docente, } \\
\text { dominio afectivo, } \\
\text { procesos matemáticos, } \\
\text { formación docente, } \\
\text { matemáticas, } \\
\text { actitudes, } \\
\text { creencias. }\end{array}$ & $\begin{array}{l}\text { El presente artículo hace parte de un macro proyecto de investigación titulado Influencia del dominio afectivo, } \\
\text { los procesos matemáticos y la práctica pedagógica del docente de Educación Básica en el rendimiento } \\
\text { académico del estudiante. Este es un trabajo de tipo cualitativo con enfoque descriptivo y documental, elaborado } \\
\text { por estudiantes pertenecientes al semillero SIEM, con el propósito de hacer una revisión bibliográfica de las } \\
\text { diferentes investigaciones y aportes teóricos que se han realizado en torno a este tema, obteniendo un panorama } \\
\text { claro y amplio sobre el objeto de estudio. Tomando como punto de partida la revisión bibliográfica de } 32 \\
\text { artículos de investigación que han sido publicados en las tres últimas décadas, dentro de las cuales se encuentran } \\
\text { libros, artículos de revistas indexadas, así como trabajos de pregrado, maestría y doctorado. Para la revisión } \\
\text { bibliográfica se tuvo en cuenta varias etapas: búsqueda de antecedentes por cada constructo, recopilación } \\
\text { de antecedentes, selección de información representativa, categorización de cada uno de los constructos y } \\
\text { sistematización. Los resultados arrojados permitieron sustentar los fundamentos teóricos y epistemológicos de } \\
\text { cada uno de los constructos que luego harán parte del marco teórico de la investigación adelantada. }\end{array}$ \\
\hline
\end{tabular}

\section{Introduction}

Mathematics is considered one of the most important sciences, because, among many other things, it is essential for the cognitive development of people, it allows for inference, enables a lucid mind and motivates thinking and a critical attitude towards a problem situation.
In the 21 st century it has become evident that there is a need to educate towards the formation of upright citizens with the ability to reason, communicate, and solve problems, that is to say, to form mathematically competent beings who are able to strengthen and enrich the five mathematical processes at the same time as they develop the contents associated with the five mathematical

*Corresponding author.

E-mail address: barbosadayanapaolag@ufps.edu.co (Dayana Paola Gómez Barbosa) 
thoughts (numerical thinking, spatial thinking, random thinking, variational thinking, and metric thinking).

It is for this reason that we present below a progress of the research project, which is associated with a first stage that is the conceptual review, where we hope to find the various authors who have studied the affective domain, attitudes, beliefs and emotions, mathematical processes, and the role of educational practice in basic education teachers toward mathematics.

From the theoretical and conceptual point of view, it is necessary to emphasize that the same authors during their review have referred to the basis of pedagogical practices in the area of mathematics towards the relevance of knowing the conceptions of teachers and thus assuming a position of equilibrium in the face of the relation that exists between teacher training and professional performance, That is, it is very important to recognize the epistemology of the teacher as a basis for understanding the actions that underlie the teaching-learning process in the sciences, since explicitly or implicitly it can constitute an obstacle to the development of effective teaching practice.

\section{Materials and methods}

This is a qualitative work with a descriptive and documentary approach. Thus, we took as a starting point the bibliographical and conceptual review of 32 research articles that have been published in the last three decades, among which are books, articles from indexed journals, as well as undergraduate, master's and doctoral papers, obtained from databases of the Universidad Francisco de Paula Santander. For the bibliographic review, several stages were taken into account, among which the following stand out: search for background for each construct (affective domain, mathematical processes and pedagogical practices), collection of background focused on mathematical education and teacher training.
In order to categorize each of the articles, the most important items to be taken into account for the construction of the state of the art were extracted from them, among which we find Research question, objectives, theoretical references, methodology, instruments, results and conclusions.

\section{Results and discussion}

In the conceptual tour that has been carried out of each of the constructs, several investigations have been found that have allowed to extend the vision and to be the theoretical foundation for each of the constructs of this study. The following is the conceptual analysis of each construct.

\section{Affective Domain}

The work carried out by Caballero, Cárdenas and Gómez (2014), takes the description of the affective domain of McLeod (2006), but adding it an important aspect in mathematics and it is the resolution of mathematical problems (RPM), where the author understands that each one of these affects influences the others, being the emotions determined more strongly by the beliefs and the attitudes. During this section a hierarchy is made according to the influence of the three variables with respect to the resolution of problems. In a first point of the hierarchization we find the emotions towards mathematics and RPM, in this construct the author makes relation to the emotions with anxiety that is why Anderson (cited by Caballero, Cárdenas and Gómez del Amo, 2014) points out mathematical anxiety as an emotional response to mathematical problems and mathematical language, considering mathematical anxiety as an involuntary emotional response. In a second position are the attitudes towards mathematics and RPM, that the attitudes towards mathematics and RPM are evaluative predispositions produced before this area or mathematical activity (positive or negative), conformed on the basis of a series of convictions and feelings, which determine personal intentions and influence behavior (favorable or unfavorable). The 
manifestation of these predispositions can occur, among others, through ideas, perceptions, tastes, preferences, opinions, beliefs, emotions, feelings, tendency to act or behavior (Caballero, Cárdenas and Gómez del Amo, 2014). On the basis of the ranking carried out in this article, results were obtained such that between $11 \%$ and $48.1 \%$ of teachers state that they do not evaluate (or take into account) affective domain; and between $7 \%$ and $30.1 \%$ state that it is not very important (or they do not agree very much) to take these aspects into account in the evaluation of problem solving in mathematics. In accordance with the above, we see that there are many teachers who do not give the necessary importance to affective mastery, since they are based simply on evaluating content and not on evaluating knowledge and learning, and this may be associated with the beliefs and conceptions that teachers have about assessment, about mathematics, or about problem solving; as well as some social and pedagogical circumstances, which require them to make certain decisions about their evaluation practices.

Continuing other research, they have focused on different descriptors, not seeing the whole affective domain but only one component of it, as is the case of the work of Gamboa and Moreira (2017), who focused on beliefs through the teaching of mathematics, this research was based on a mixed design of two stages or phases: the first was quantitative and the second qualitative. In the first, the attitudes and beliefs of students and teachers towards mathematics were identified. In the second, the meanings and interpretations of these perceptions in the participants were deepened. A c c o r d ing to the analyses that were carried out on the beliefs towards the discipline, it was found that Gamboa and Moreiro (2017) divided them into three aspects:

1. Those related to beliefs about mathematics (instrumentalist, Platonic and problem solving)

2. Individuals' beliefs about themselves in mathematics
3. Beliefs associated with the role of the teacher within the context of the classroom (on his or her didactic tendency: traditionalist, technological, spontaneous, investigative; image of a good mathematics teacher and perception of the teacher).

It should be noted that many students' taste in mathematics is associated with their academic performance. If the grades obtained by them in the evaluations are high, their self-confidence with respect to their development in the subject is strengthened and they are motivated in their study, the same is true for the teacher, if he or she observes that many of the students obtain good results then the teacher will improve and be more encouraged to reinforce his or her pedagogical practice. Otherwise, if the disposition towards it is unfavorable and generates sadness, frustration, pressure and a series of negative thoughts, the teacher will also become frustrated and will not seek solutions to the situation.

According to the two points of view described on beliefs, López and Alsina (2016) complement their work with the analysis of beliefs based on three main factors applied to early childhood education teachers and primary education teachers:

Cognitive factors, understanding these as those that help the student to know, this category has also been divided into four subcategories: intelligence, memory, comprehension and mental and written calculation. Procedural factors, are those that allow the student to know how to do, in this category the subcategories have been considered: reasoning, communication, connections and problem solving. Finally, attitudinal factors are those that help the student know how to be. The four subcategories that have been defined are: interest, effort, participation and self-concept. (López and Alsina, 2016, p. 7)

From these categories and the analysis of each one of them, it was obtained that future teachers assign the acquisition of three types of factors to good math students: first, they consider intelligence and memory among the most important cognitive 
factors, secondly, through the attitudinal factors they indicate interest and self-concept and finally in the procedural factors the most developed are problem solving and communication, that is to say they are categorized according to what the student is capable of knowing how to do, knowing how to know and knowing how to be.

Based on the beliefs that teachers may have in front of their class Ponte (1999), in his research analyses these conceptions of trainee teachers and the capacity they present when creating teaching tools and strategies for teaching mathematics, looking at the beliefs from two points of view: the teachers' beliefs about problem solving and the beliefs regarding the use of ICTs as an object of pedagogy.

Therefore, Camacho, Hernández and Socas (1995) carry out a study of partial data that consists of analyzing the changes that students experience throughout their Bachelor's degree in Mathematics, in matters such as conceptions and beliefs, attitude towards Mathematics and its various branches, as well as behavior towards Problem Solving, strategies, creativity and beliefs. This research proposes the goal of observing the states of opinion and attitudes that occur in students in the Faculty of Mathematics after five essentially Mathematics training courses and their relationship with the profile of the Secondary School Mathematics teacher, as well as contrasting these opinions and attitudes at the end of the degree with those of graduates in related branches whose intention is to become Mathematics teachers. And it is from this analysis that we conclude that if we consider the profile of the teacher, in which significant learning in the form of problem solving is chosen, where mathematical activity plays a central role, as well as less abstract aspects and "for everyone", creativity, problem solving, the use of conjectures and checks before the test, construction of knowledge, etc; are basic in this approach, however, when they finish their studies they continue to see teachers who do not put their profile into practice and who, on the contrary, remain in traditionalist training.

Further analysis of the research of Hidalgo, Maroto and Palacios (2015) shows, first, that beliefs acquired in the training period are difficult to change with experience or continuing education, and second, that they support and help educational practices to be transcendental and promote in students a real like for the area.

The tour shows different theoretical approaches, but the work done by Caballero, Blanco and Guerrero (2009) stands out. He adopts Weiner's theory, which explains that the result of an event produces a general positive or negative reaction, depending on whether success (happiness) or failure (frustration) is perceived; followed by an assessment of the result, a cause is sought for this reaction and from there emotions such as pride, despair, anger, gratitude. Many of the successes or failures at school do not always depend on the cognitive abilities of the students, but on the development of emotional intelligence, the idea is that students who are going to be teachers should develop the ability to apply problem-solving strategies to reduce negative attitudes through self-regulation in both school and everyday situations. Finally, the work of ÁlvarezGonzález (2016) highlights the feelings of anxiety and distress that students may experience in their learning process.

\section{Mathematical Processes}

In the last decade several investigations have been developed that take as a central theme the mathematical processes. For example, the work carried out by Alsina and Coronata (2015); Maurandi, Alsina and Coronata (2018) which aimed to determine the presence or absence of mathematical processes in the practice of teachers of children from 4 to 8 years, taking as a reference the MKT model of Hill, Ball and Schilling (2008) and the NCTM. The instrument was tested by 17 experts in mathematics education from Chile, Spain, the United States and 
Argentina, drawing conclusions that it is vitally important for teachers to have an assessment tool that systematically describes the presence (or absence) of mathematical processes in teaching-learning practices in Early Childhood Education. Research was also found that takes the Ministry of National Education (MEN) as a reference framework, as is the case of Acevedo, Cifuentes, Casasbuenas and Perez (2012); Escudero, Rojas and Llanos (2012). Firstly, Acevedo et al. (2012) carry out an analysis of mathematical processes, characterizing them and arranging them into three groups (problem posing and solving, mathematical reasoning and mathematical communication) in order to determine their influence on the educational act. In second place Escudero et al. (2012), highlight the role of mathematical competence to carry out mathematical processes, considering in this study a sixth process "having positive attitudes towards mathematics".

Another research trend has not looked at mathematical processes as a whole, but on the contrary has looked at each one separately, such is the case of research that has focused its attention on Problem Solving. There are several works that characterize mathematical problem solving as an effective way to teach mathematics, based on an analysis of the main concepts, paradigms and models, which through the historical development of this science have shaped the fundamental didactic conceptions about problem solving (Berenguer Martínez, 2003; Navarrete and Navarro, 2010; Montero et al., 2013). Likewise, the research of Contreras and Carrillo (1996) stands out, who take Schoenfeld as a reference framework to elaborate a profile of a teacher's didactic tendencies based on his or her beliefs about the role of problem solving in the classroom. The results showed that the absence of information on how teachers understand problem solving could be one of the reasons why improved teaching is not very successful. It is also important to highlight the work of Pérez (2008) who creates a model for problem solving. His purpose was to institute a model that would serve as a support for the teacher in teaching mathematical problem solving and for the student as a tool for success in tackling a problem.

Other works have focused on the mathematical process of Reasoning and Testing. We highlight works such as Codina and Lupiañez (1999) who sought to determine at what point does the use of computer systems in teaching facilitate or improve the performance of mathematical demonstrations? Using as an instrument a geometric software called CABRI its conclusions suggest that understanding and mastering the demonstration of a mathematical result helps a lot in the understanding of it. But you can't take advantage of a demonstration if you don't really understand what it is, what its role is, and where its strength lies; and this is something that students are not clear about, and what may be worse, is something that the teacher is not aware of. We also found research that is interested in promoting mathematical reasoning in higher education, as is the case with Camacho (2012); Larrazolo, Backhoff and Tirado (2013). The first research proposed problem-solving strategies based on the Polya model. Its sample was comprised of second year students of the Diploma Level of the Pedagogy career. Their findings reveal that teachers must make mathematics more attractive to students, because if students are made to learn mathematics in an appropriate and enjoyable way, they will be more successful in their school performance. On the other hand, the second research wanted to investigate the mathematical reasoning skills acquired by Mexican students who graduate from high school and aspire to enter Mexican public universities. Its sample consisted of 96,400 students from five public Mexican universities (for each university the student cohorts of 2006 and 2007 were selected). The results show very low performance of Mexican students, especially in the area of mathematics. For example, on the Math Skills test, $40.6 \%$ of students are at the insufficient level of learning, while $39.1 \%$ are at the elementary level.

On the other hand, less abundant are the works that have focused on the mathematical process of 
connections, even the works found are from the last four years, that is, until now the need to investigate this topic has begun to emerge. For example, we found a work that has NCTM as a theoretical reference, as is the case of Solórzano (2016) who wanted to investigate if, after favoring the process of intramathematical connection, EPP (students for teachers) manage to pose powerful, interesting and relevant questions, which motivate them to search for answers and to open up new mathematical concepts. We worked with a sample of 21 students from the course of Introduction to the Complex Variable of the Mathematics Teaching career at the UCR. The results highlight the motivation of the students, which was much higher than that presented by some of them in previous courses they had taken with the same teacher.

We also found works focused on the mathematical process of communication, as is the case of Jiménez, Suárez and Galindo (2010) who worked with the research approach: Symbolic Interactionism (SI), under which the role played by the actors of school culture was analyzed (teachers, students and knowledge). They also analyzed different strategies that allow the classroom to become a living environment of interactions, where the subject is given meaning in its interrelationship with the culture of the group; these strategies are based on the use of spaces for group work, on the debate and confrontation of interpretations and narratives, and on the permanent questioning of teachers. In this same sense, the research of Jiménez, Jiménez and Jiménez (2014) had the objective of favoring the development of the competence communication and representation in the process of teaching and learning mathematics. They worked with a sample of 20 teachers from the math area of the Barranquilla District, 46 students from the sixth grade of the District Educational Institution for the development of Human Talent, from which the experimental group and the control group were chosen, with 23 students each, his age varies from 10 to 12 years. In their conclusions they established the importance of the development of mathematical competencies, when linked to communication and representation, as a starting point to understand, interpret and pose mathematical models that lead to solve problems, coinciding with the results mentioned in the research of Hernández-Suárez, Prada-Núñez and RamírezLeal (2017). On the other hand, research was found that sought to analyze the teaching work of teachers of the Bachelor of Mathematics at the Universidad Pedagógica y Tecnológica de Colombia (UPTC) as an initial step to improve classroom practices, as is the case of Leguizamón (2016), who worked with a sample of three teachers of the Bachelor of Mathematics under an Ontosemiotic Approach to Cognition and Mathematical Instruction. The findings of this study revealed that among the most frequent interactions in the classroom of one of the three teachers are: the short question by the teacher, as well as the short individual response by the student; the short clarifications and explanations by the teacher; the broad explanation of the teacher and his or her self-representation, therefore from the classification made by the Author on the interactions in the classes, it could be stated that the interactions of this teacher are of the traditional-technological type (López-García \& Gutiérrez-Niño, 2018).

Finally, the research that has focused on the mathematical process of representation was analysed. For example, the work of Rojas (2012) dealt in a general way with representation in mathematics and the use of a diversity of such representations. In addition, it was described how essential representation systems are for learning mathematics. Last but not least, we present the research of Badano and Dodera (1999) who try to analyze whether the student's representation of mathematics influences his or her academic performance. The sample was made up of a group of students studying Mathematics in the Common Basic Cycle (CBC) at the University of Buenos Aires. It should be noted that these students were enrolled in degrees from the Faculties of Architecture and Urbanism, Agronomy and Veterinary Medicine, Pharmacy 
and Biochemistry, Medicine and Economics. The results showed that the students who applied had a more negative representation of mathematics, and that a positive evaluation was linked to higher academic performance. The conclusions reflect that a high mathematical representation could influence the decrease in the number of students who do not succeed in the subject and that a previous failure in the study of the subject Mathematics has a negative impact on the student's assessment of mathematics.

\section{Pedagogical practice}

Over the years, education at its various levels undergoes unpredictable and decisive changes for the educational community, since it lives in a constant state of change based on the demands of society. We must take into account that pedagogical practices are not alien in education. Therefore, several researches have taken as a central axis the study of teachers and therefore the reflection of their pedagogical practices in their different dimensions, mentioned in the teaching framework (2013), these dimensions are: learning environments, learning strategies, professional responsibilities and last but not least class planning and preparation. Each one of these dimensions is for the teacher to understand how he/she plans; how he/she teaches; how he/ she communicates; how he/she creates friendly environments; how he/she uses evaluation for the growth of his/her students; among other aspects they serve to carry out a process of self-reflection and to compare himself/herself with those practices considered of high level and thus to improve his/her own teaching practice. Among the investigations in the category of pedagogical practices we can obtain that some are studied from the field of mathematical education, for example Enamorado (2012), aims to analyse whether there is coherence between teaching practices and the results obtained by students on standardized tests, it is stressed that in order to achieve a quality education, teaching staff are required who are capable of adapting the current context to the context of the classroom in such a way that their subjects are articulated with the daily experiences experienced by the student, in the same way to achieve that the student has a close relationship with society with which he can develop and potentialize his capacities, but it must be taken into account that it is necessary to understand from which approach one wants to educate. Likewise, Duarte, Carmona \& Escorcia (2018) analyze the characterization of the teaching role in research and its relationship with pedagogical practice. Taking as a reference the guidelines of the Ministry of National Education, to define the research competencies that are necessary in areas of being a researcher in the national context. It should be noted that a good researcher is able to analyze the context that surrounds the student achieving with greater ease the articulation of this with their course. The sample of this research is 10 Mathematics graduates linked to an educational institution in the city of Barranquilla where, through focus groups, interviews and records of field journals, the conclusion was reached that the teachers who graduated from the program do not usually include research in their teaching practices, because the vision with which they were left by their undergraduate teachers was not the best. They believe, therefore, that this is the main reason why their pedagogical practice is very static and the school environment in many cases is not efficient.

Other investigations have focused on the category of learning strategies, being conceived as the abilities that the teacher has for the management of the relations in the classroom, within these we can obtain that some are studied from the field of mathematics for example Vizaca \& Mier (2015) sought to identify the didactic trends of some mathematics teachers and their conceptions of the role of educational media in the teaching and learning process of mathematics. Using as an instrument the Epistemological Questionnaire (EQ) for the analysis of the epistemological belief system (Schommer, 1990), from the dimensions that compose it, which evaluates the degree of development and maturity of the same. From this its results reveal 
the predominance of oral methods, particularly explanation, which, combined with exposure, constitutes the most frequent alternative for the teaching of mathematical contents. Articulated with this research is Garcia (2012), which aims to analyze what is the effect of using cooperative learning strategies in improving the quality of teaching practice of teachers in the area of mathematics at the secondary level of the Educational Institution "Señor de la Soledad" - Huaraz, Ancash Region in 2011? using for the collection of information instruments such as: observation guide, monitoring sheets, follow-up and teacher interviews. Taking 11 appointed teachers from the secondary level as a sample. The results show that the use of cooperative learning strategies significantly improves the quality of teachers' pedagogical practices. Achieving to affirm that cooperative learning strategies have more advantages than competitive and individualistic ones during the pedagogical practice of teachers.

At the same time, we find research that characterizes pedagogical practices based on the use of a-didactic situations, as is the case of Jiménez \& Sánchez (2019), having as methodology a qualitative approach, under the action research technique. With the participation of four math teachers and their corresponding groups of students. The research allowed us to perceive that the teacher confronts the vision of his class with what is observed by others and through collective reflection on his practice, he takes a different attitude by taking the dynamics of a class in a different way. The results showed that when a-didactic situations are implemented in the classroom, a dynamic class is generated with the students, generating changes in attitudes and emotions towards learning. It is also worth mentioning the research of Leguizamón, Patiño Porras \& Suárez Sotomonte (2015), which aims to identify the didactic trends of some mathematics teachers and their conceptions about the role of educational media in the teaching and learning processes of mathematics. The methodology was developed under a qualitative paradigm, with a case study design, in which three teachers from public educational institutions and four teachers from private educational institutions participated. Due to the questionnaire applied and the observations made. The results show that teachers often use educational media as a motivational tool that allows them to awaken students' interest in the subject, mechanization of concepts and support for the teacher. This is only the case in private educational institutions, since public educational institutions do not have enough tools and in these institutions the traditional is still predominant.

The use of ICTs is the boom of society, since from the twentieth century was considered the information age, which is why Mallqui (2015), seeks to determine what relationship exists between the pedagogical practices of teachers with the curricular use of ICTs and the academic performance of students in problem solving and reading comprehension from NM1 to NM4 in two schools, one in Chile and the other in Peru? Using as an instrument quantitative technique such as: documentary analysis, Likert-type survey, and qualitative techniques such as: teacher interview. This allows us to know the meanings that teachers give to the curricular use of tics. As a conclusion, they suggest that it is essential that teachers in training be trained and prepared to use this technology in terms of information and communication. Likewise, it is essential to train students in the use of ICTs. Having the children access to the computer room or tablets that the educational institution has.

\section{Conclusions}

In this article we have carried out a bibliographical review of the affective domain, mathematical processes and pedagogical practice focusing our attention on those researches that were focused on the teacher and teacher in training.

The exercise of tracing, reviewing, categorizing and systematizing the research background allowed us to learn about various methodologies, approaches and pedagogical models that have been applied for 
the improvement and innovation of pedagogical practices, mathematical processes and the affective domain of the teacher. In addition, the subcategories skills, beliefs, problem-solving, reasoning and testing, connections, communication, representation, pedagogical practices and learning strategies, allowed us to show how they influence the progress and quality of education.

To conclude, it is necessary to say that we are aware of the difficulties involved in going deeper into the educational scenario, but it is necessary to know and interpret all the factors involved in it, since, as we were able to analyze in our documentary review, there are several paradigms in relation to the teaching of mathematics, which result in a long list of opinions, highlighting those who think that mathematics is difficult to learn; are contained only for the intelligent; they tend to be boring, complex, rejected or hated by those who do not understand them. Thus, generating feelings of frustration, anguish and aversion instead of satisfaction with the achievements obtained (Martínez, 2005), a situation that makes the process of teaching and learning difficult and therefore the acquisition of good results in this discipline.

\section{Acknowledgement}

This work has been possible thanks to the support received by a group of teachers from the academic program of the Bachelor's Degree in Mathematics who, through the Research Seedbed in Mathematics Education - SIEM, have carried out an excellent process of orientation, accompaniment and development of research skills.

\section{References}

Acevedo, M., Cifuentes, V., Casasbuenas, C., Pérez, M. C., \& Pedraza, P. (2012). Procesos matemáticos. Estándares curriculares de Matemáticas del MEN.

Alfonso, M. D. C. C., \& González, J. C. N. (2014). La resolución de problemas en el proceso de enseñanza-aprendizaje de la Matemática en la ELAM. Panorama. Cuba y Salud, 5(4), 143-145. Alsina, Á. (2014). Los procesos matemáticos en las prácticas docentes: diseño, construcción y validación de un instrumento de evaluación. Edma 0-6: Educación Matemática en la Infancia, 3(2), 23-36.

Álvarez-González, C. F. (2016). La angustia, principio de posibilidad del conocimiento. Revista Perspectivas, 1(1), 30-37. https://doi. org/10.22463/25909215.968

Badano, C. I., \& Dodera, M. G. (1999). Un estudio de la influencia de la representación de la matemática en el rendimiento académico del alumno de primer año de la universidad. Educación matemática, 11(03), 79-88.

Camacho, M., Hernández, J., \& Socas, M. M. (1995). Concepciones y actitudes de futuros profesores de Secundaria hacia la Matemática y su enseñanza: un estudio descriptivo. LJ Blanco y $V$. Mellado. La formación del profesorado deficiencias $y$ matemáticas en España y Portugal, 81-97.

Carrasco, A. C., Blanco Nieto, L. J., \& Barona, E. G. (2008). El Dominio Afectivo En Futuros Maestros De Matemáticas En La Universidad De Extremadura. Paradigma, 29(2).

Codina, A., \& Lupiáñez, J. L. (1999). El razonamiento matemático: Argumentación y demostración.

Contreras, L. C., \& Carrillo, J. (1998). Diversas concepciones sobre resolución de problemas en el aula. Educación matemática, 10(01), 26-37.

Da Ponte, J. (1999). Las creencias y concepciones de maestros como un tema fundamental en formación de maestros. On research in teacher education: From a study of teaching practices to issues in teacher education, 43-50.

Duarte, S. V., Carmona, R. J. C., \& Escorcia, I. A. P. (2018). La práctica pedagógica en la investigación en educación matemática desde la perspectiva de los egresados. Universitas humanística, 86(86).

Enamorado, J. (2012). Prácticas pedagógicas de los docentes en la enseñanza de las matemáticas en el I Ciclo en las escuelas primarias del departamento de Ocotepeque. Maestría en Formación de 
Formadores de Docentes para Educación Básica. Universidad Pedagógica Nacional Francisco Morazán.

Escudero, T. R., Rojas, Á. C., \& Llanos, B. H. (2012). Procesos matemáticos ¿Qué es ser competente matemáticamente? VJ Arteta, \& y. otros, Los fraccionarios en primaria.

Gamboa Araya, R., \& Moreira Mora, T. E. (2017). Actitudes y creencias hacia las matemáticas: un estudio comparativo entre estudiantes y profesores. Actualidades Investigativas en Educación, 17(1), 514-559.

García, H., \& de Sahagun, J. (2012). El aprendizaje cooperativo para mejorar la práctica pedagógica en el Área de Matemática en el nivel secundario de la Institución Educativa "Señor de la Soledad"Huaraz, región Ancash en el año 2011.

Hernández-Suárez, C. A., Prada-Núñez, R., \& Ramírez-Leal, P. (2017). Obstáculos epistemológicos sobre los conceptos de límite y continuidad en cursos de cálculo diferencial en programas de ingeniería. Revista Perspectivas, 2(2), 73-83. https://doi. org/10.22463/25909215.1316

Hidalgo Alonso, S., Maroto Sáez, A., \& Palacios Picos, A. (2015). Una aproximación al sistema de creencias matemáticas en futuros maestros. Educación matemática, 27(1), 65-90.

Jiménez, A., Suárez, N. Y., \& Galindo, S. M. (2010). La comunicación: eje en la clase de matemáticas. Praxis \& Saber, 1(2), 173-202.

Jiménez-Espinosa, A., \& Sánchez-Bareño, D. M. (2019). La práctica pedagógica desde las situaciones a-didácticas en matemáticas. Revista de Investigación, Desarrollo e Innovación, 9(2), 333-346.

Larrazolo, N., Backhoff, E., \& Tirado, F. (2013). Habilidades de razonamiento matemático de estudiantes de educación media superior en México. Revista mexicana de investigación educativa, 18(59), 1137-1163.

Leguizamón Romero, J. F., Patiño Porras, O. Y., \& Suárez Sotomonte, P. (2015). Tendencias didácticas de los docentes de matemáticas y sus concepciones sobre el papel de los medios educativos en el aula. Educación matemática, 27(3), 151-174.

Leguizamón-Romero, J. F. (2017). Patrones de interacción comunicativa del profesor universitario de matemáticas. Un estudio de caso. Praxis \& Saber, 8(16), 57-82.

Lizarazo, J. A. C., Carrasco, A. C., \& Del Amo, R. G. (2014). La evaluación del dominio afectivo en matemáticas. Revista INFAD de Psicología. International Journal of Developmental and Educational Psychology., 7(1), 333-342.

López, A. M., Alsina, Á., \& Segure, C. C. (2018). Los procesos matemáticos en la práctica docente: análisis de la fiabilidad de un cuestionario de evaluación. Educatio Siglo XXI, 36(3 Nov-Feb1), 333-352.

López, P., \& Alsina, Á. (2016). Creencias de los futuros maestros sobre la aptitud matemática: consideraciones para promover procesos de cambio en la formación inicial. Bolema: Boletim de Educação Matemática, 30(56), 892-905.

López-García, J. D., \& Gutiérrez-Niño, D. (2018). Efecto del uso de la herramienta "realidad aumentada" en el rendimiento académico de estudiantes de Educación Básica. Revista Perspectivas, 3(1), 6-12. https://doi. org/10.22463/25909215.1464

Mallqui, J. (2015). Prácticas pedagógicas de los docentes con el uso curricular de las TIC y el rendimiento académico en resolución de problemas y comprensión lectora de los alumnos de primero a cuarto medio en dos colegios uno de Chile y otro de Perú-2014 (Doctoral dissertation, Tesis de Mastría, Universidad de Chile, Santiago de Chile).

Márquez, E. A. J. (2014). Estrategia didáctica para desarrollar la competencia "comunicación y representación" en matemática. Escenarios, 12(1), 17-33.

Masachs, A. M., Camprubí, G., \& Naudi, M. M. (2007). Los entornos de validación en la resolución de problemas matemáticos. Revista CPU-e, (4), 9. 
Montero Ramírez, O., Herrera, H., Ramón, R., Proenza Garrido, Y. C., Leyva Leyva, L. M., \& Mulet González, J. C. (2014). Consideraciones sobre el proceso de resolución de problemas matemáticos en la escuela primaria. Revista Didasc@lia: Didácticay Educación, 5(1).

Oviedo, M. C. (2012). Estrategias para promover la indagación y el razonamiento lógico en la educación primaria desde la didáctica de la Matemática. Revista Electrónica Educare, 16(2), 95-111.

Rojas, P. J. (2012). Sistemas de representación y aprendizaje de las matemáticas. Revista Digital: Matemática, Educación e Internet, 12(1).

Sánchez, N. M. (2003). La resolución de problemas matemáticos. Una caracterización histórica de su aplicación como vía eficaz para la enseñanza de la matemática. Pedagogía Universitaria, 8(3).

Solórzano, L. S. (2016). Induciendo a la formulación de preguntas como producto de conexiones intramatemáticas. Revista del Congrés Internacional de Docència Universitària $i$ Innovació (CIDUI), (3).

Vizaca, A., \& Mier, M. M. (2015). Relación entre creencias epistemológicas sobre la matemática y métodos de enseñanza en profesores de esta asignatura en la secundaria básica. Psicogente, 18(33). 